\title{
Study of Physical, Psychological, and Spiritual Impact of Family Caregiver In Home-Based Stroke Treatment: A Systematic Review
}

\author{
Anggi Stiexs, Nur Chayati* \\ Master of Nursing, Post Graduate Program, Universitas Muhammadiyah Yogyakarta, Bantul, Indonesia
}

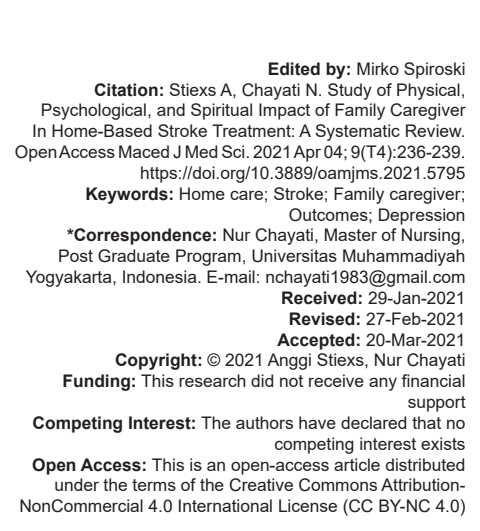

\section{Introduction}

The World Health Organization 2016 reported that stroke is one of the three leading causes of death $(21.2 \%)$, following by ischemic heart disease $(8.9 \%)$, and diabetes mellitus (6.5\%) [1]. Stroke attacked was not only impact on patients experience but also on families who take care of them. Families who cared for the elderly stroke should adapt holistically, physically, psychologically, and spiritually [2].

Family members are usually the primary caregivers for stroke patients [3]. With the family's support, post-stroke patients can improve their ability to perform daily activities independently. However, caring for long period will be a burden for family caregiver live. The disease burden is multidimensional responses to physical, psychological, emotional, social, and financial pressures [4]. It has an impact on reducing the level of life satisfaction [5]. Furthermore, it affects family caregiver to discontinue caring to their relatives at home [6].

Home care tasks may produce unpleasant feeling, causing psychological stress, and physical exhausting. Psychological stress felt by caregivers includes shame, anger, tension, anxiety, fatigue, uncertainty, and feelings of guilt, [7]. Many single studies have reported the family caregiver feels, but a review that analyze home-based treatment impacts on the family caregiver is still required. The study aims to review the home health service of stroke patients on physical, psychological, and spiritual of family caregiver.

\section{Methods}

The study used a systematic review design, that summarizes the results of primary research articles to present more comprehensive understanding.

\section{Literature search}

Data were collected using three databases, likely PubMed, ProQuest, and Ebsco. The keywords used were "Stroke, Apoplexy, Cerebrovascular Accident, Vascular 
Accident, Home Care Services, home care, Home Health Care, Domiciliary Care, Physical, Physics, Psychological Factors, Psychological Side Effects, Psychosocial Factors, Spirituality." The keywords were combined using the Boolean word AND, OR. No gray literature was involved in the review. Selected articles should follow the inclusion criteria, such as research interventions involved the stroke patients and family, intervention was conducted at home by professional or health staff with outcomes seen in the physical, psychological, and/or spiritual, study design was quasi-experimental, pre-experimental, and RCT. Other criteria were the articles were published between 2014 and 2019.

\section{Data collection}

From the certain keywords, the number of articles obtained from Pubmed was $(n=1301)$, Ebsco $(n=17,890)$, Proquest $(n=337)$, totally 19,528 articles. Finally, after screening process and then conforming to the inclusion and exclusion criteria, five articles were eligible to be reviewed. First author conducted a review of each article, while the second author did a double check. When differences were met, a discussion of both authors was conducted to find an agreement. The review process' was described in Figure 1.

\section{Results}

The physical impact of home health intervention for stroke survivors felt by the family for instance may reduce physical fatigue during caring for patients [8]. Psychological responses seem can lower the incidence of depression and levels of anxiety in the family [9], [10], [11], [12]. The families also become more independent doing their activities and give motivation to patients more confidently [9], [10]. Unfortunately, there are no articles viewed the spiritual aspect of family. Detailed findings are explained in Table 1.

\section{Discussion}

Stroke is an acute disease that can cause longterm problems and require treatment and rehabilitation outside of hospitalization. Continuity and integration of care in home-based outpatient rehabilitation can be made alternative to stroke patients [13].

Healing process of post-stroke patient will be more effective if combined with the family function

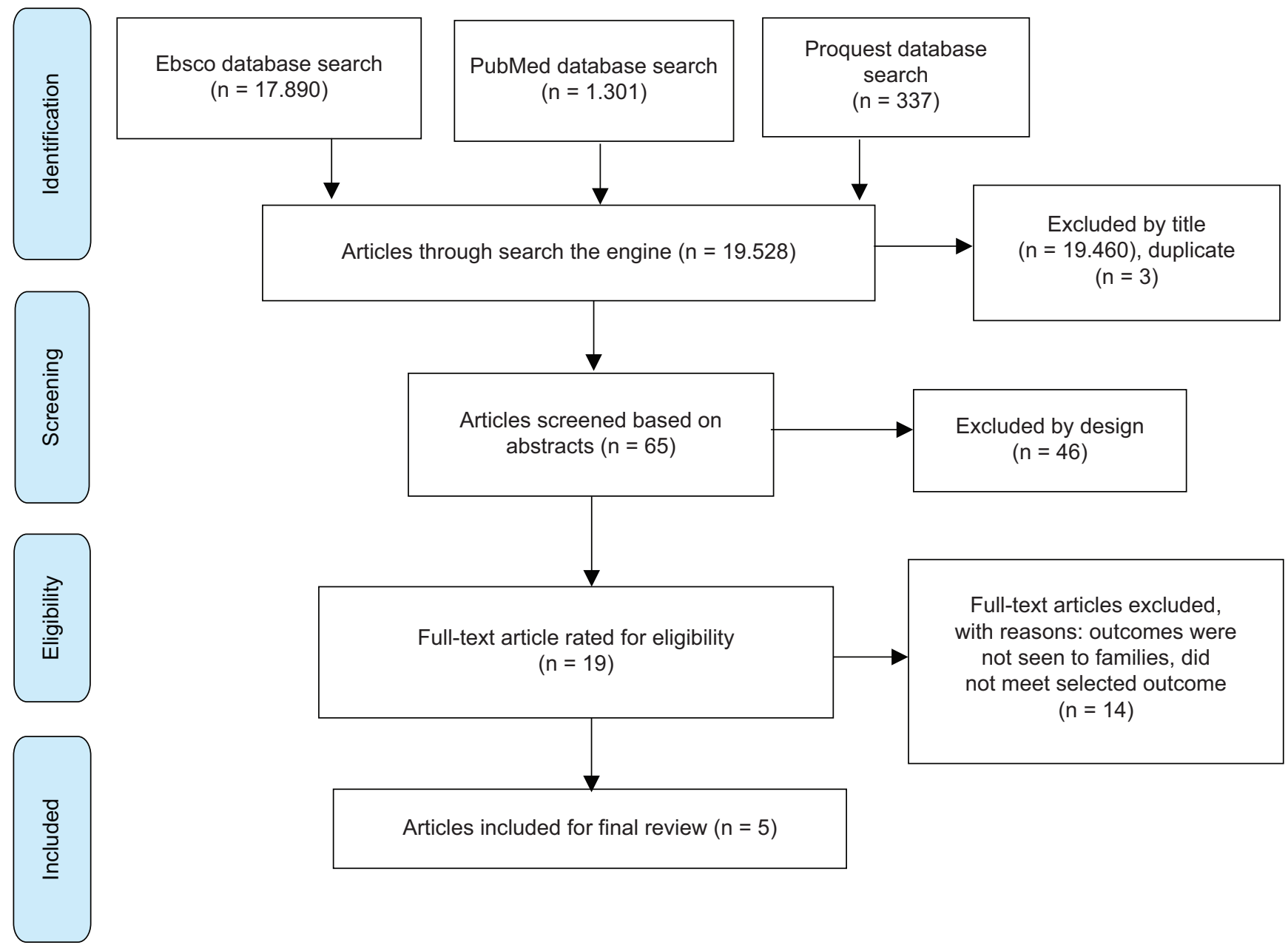

Figure 1: The process of search and review the articles 
Table 1: The articles characteristic

\begin{tabular}{|c|c|c|c|c|c|c|c|}
\hline \multirow[t]{2}{*}{ Author } & \multirow[t]{2}{*}{ Subject } & \multirow[t]{2}{*}{ Home health Intervention } & \multicolumn{4}{|c|}{ Outcome measure } & \multirow{2}{*}{$\begin{array}{l}\text { Duration of } \\
\text { intervention }\end{array}$} \\
\hline & & & Physical & Psychological & Spiritual & Other outcomes & \\
\hline $\begin{array}{l}\text { (Wu et al., } \\
2017 \text { ) }\end{array}$ & 12 & Cognitive behavioral therapy & - & $\begin{array}{l}\text { Decreased anxiety } \\
\text { levels in families caring } \\
\text { for patients }\end{array}$ & - & $\begin{array}{l}\text { The family felt helped } \\
\text { because patients could more } \\
\text { independently do their activities }\end{array}$ & 3 months \\
\hline $\begin{array}{l}\text { (Cheng } \\
\text { et al., 2018) }\end{array}$ & 126 & $\begin{array}{l}\text { Psychoeducation (evidence-based therapeutic interventions } \\
\text { for patients and their loved ones who provide information } \\
\text { and support to better understand and deal with the disease) }\end{array}$ & - & $\begin{array}{l}\text { - The family felt happy } \\
\text { - Stress and family } \\
\text { burden was reduced. }\end{array}$ & - & $\begin{array}{l}\text { The family always motivated } \\
\text { patients to carry out daily } \\
\text { activities }\end{array}$ & $\begin{array}{l}\mathrm{T} 1=1 \text { week } \\
\mathrm{T} 2=3 \text { months } \\
\mathrm{T} 3=6 \text { months }\end{array}$ \\
\hline $\begin{array}{l}\text { (Gauthier } \\
\text { et al., 2017) }\end{array}$ & 224 & Training motor interventions & $\begin{array}{l}\text { Physical } \\
\text { fatigue }\end{array}$ & Reducing stress & - & - & 6 months \\
\hline $\begin{array}{l}\text { (Kamal } \\
\text { et al., 2016) }\end{array}$ & 300 & Training using video-based home rehabilitation programs & - & $\begin{array}{l}\text { A decrease in the } \\
\text { incidence of depression }\end{array}$ & - & $\begin{array}{l}\text { Video-based rehabilitation } \\
\text { programs helped families on } \\
\text { taking care of patients }\end{array}$ & 12 months \\
\hline $\begin{array}{l}\text { (Trihandini } \\
\text { et al., 2018) }\end{array}$ & 30 & Holistic care and praying & - & $\begin{array}{l}\text { A decrease in anxiety } \\
\text { levels in families }\end{array}$ & - & - & 5 weeks \\
\hline
\end{tabular}

enhancement. It showed that family member become more confidence, so it improved patient's engagement and allows them to do activities as much as possible independently [14]. There is a significant relationship between family support and patient's independence of daily life activities [15]. If the patient is always motivated to do daily activities positively, it will accelerate the healing [16]. Individuals with high motivation will have a proper frequency of self-care [17].

A previous study revealed that educated caregivers experiencing physical health problems and needed more treatment than non-caregivers. There was a $23 \%$ increase in stress hormones in the caregiver. Other results showed that caregivers produced low antibody production, experience high sleep disturbance, fatigue, and inadequate diet [18]

Individual psychotherapy could be a choice to overcome the caregiver's health problems. Psychotherapy is a therapeutic method that aims to improve the human by examining feelings, attitudes, ways of thinking, and how the individual behaves. The types of psychotherapy applied to psychosocial caregiver problems include thought-stopping therapy, cognitive therapy, progressive muscle relaxation therapy, and psychoeducation therapy [19]. The purpose of psychoeducation on caregivers is to increase understanding of family members to disease journey, reduce recurrence of stroke, and increase family and client roles [20]. Psychoeducation given to families can significantly reduce anxiety and burden of caregivers especially when the patients were treated at hospital [21].

Spiritual support is one of the strategies or external family coping in addition to adapt with environment change [22]. The dimensions of spiritual support that can be done by families include intrapersonal (self), interpersonal (other people and the environment), and transpersonal relationships (God or a power greater than oneself) support [23]. Factors that influence family's spiritual support are family behavior and family burden in caring for older adults after stroke. The family burden is the level of family distress experienced due to family members who experience a chronic illness that can cause increased emotional and economic stress from the family [24]. Spiritual practice can increase hope, enthusiasm, self-confidence, and psychological comfort that brings strength to the elderly after a stroke [25].

\section{Conclusion}

Rehabilitation process of stroke patients treated at home also affects the family well-being. This review concluded that home-based intervention could help physical problem of family caregiver's by reducing fatigue, supporting emotional with decreasing depression and family anxiety. Unfortunately, no reports showed the benefits of home care to the spiritual aspects of the family yet.

\section{References}

1. Deng C, Lu Q, Yang L, Wu R, Liu Y, Li L, et al. associated with stigma in community-dwelling stroke survivors in China: A crosssectional study. J Neurol Sci. 2019;407:116459. https://doi. org/10.1016/j.jns.2019.116459

PMid:31627181

2. Braun LT, Grady KL, Kutner JS, Adler E, Berlinger N, Boss R, et al. Palliative care and cardiovascular disease and stroke: $\mathrm{A}$ policy statement from the American Heart Association/American Stroke Association. Circulation. 2016;134(11):e198-225. https:// doi.org/10.1161/CIR.0000000000000438

3. Hebert D, Lindsay MP, McIntyre A, Kirton A, Rumney PG, Bagg S, et al. Canadian stroke best practice recommendations: Stroke rehabilitation practice guidelines, update 2015. Int J Stroke. 2016;11(4):459-84. https://doi.org/10.1177/1747493016643553 PMid:27079654

4. Graf R, LeLaurin J, Schmitzberger M, Freytes IM, Orozco T, Dang $S$, et al. The stroke caregiving trajectory in relation to caregiver depressive symptoms, burden, and intervention outcomes. Top Stroke Rehabil. 2017;24(7):488-95. https://doi. org/10.1080/10749357.2017.1338371

PMid:28618848

5. Hankey GJ, Blacker DJ. (2015). Is it a stroke? BMJ. 2015;350:h56. https://doi.org/10.1136/bmj.h56

PMid:25591946

6. Vloothuis JD, Mulder M, Nijland RH, Goedhart QS 
Konijnenbelt M, Mulder $\mathrm{H}$, et al. Caregiver-mediated exercises with e-health support for early supported discharge after stroke (CARE4STROKE): A randomized controlled trial. PLoS One. 12019;4(4):e0214241. https://doi.org/10.1371/journal. pone. 0214241

PMid:30958833

7. López-Espuela F, González-Gil T, Amarilla-Donoso J, CordovillaGuardia S, Portilla-Cuenca JC, Casado-Naranjo I. Critical points in the experience of spouse caregivers of patients who have suffered a stroke. A phenomenological interpretive study. PLoS One. 2018;13(4):e0195190. https://doi.org/10.1371/journal. pone.0195190।

PMid:29617425

8. Gauthier LV, Kane C, Borstad A, Strahl N, Uswatte G, Taub E, et al. Video Game Rehabilitation for Outpatient Stroke (VIGoROUS): Protocol for a multi-center comparative effectiveness trial of in-home gamified constraint-induced movement therapy for rehabilitation of chronic upper extremity hemiparesis. BMC Neurol. 2017;17(1):109. https://doi. org/10.1186/s12883-017-0888-0

PMid:28595611

9. Wu S, Chalder T, Anderson KE, Gillespie D, Macleod MR, Mead GE. Development of a psychological intervention for fatigue after stroke. PLoS One. 2017;12(8):e0183286. https:// doi.org/10.1371/journal.pone.0183286 PMid:28817725

10. Cheng HY, Chair SY, Chau JP. Effectiveness of a strengthoriented psychoeducation on caregiving competence, problemsolving abilities, psychosocial outcomes and physical health among family caregiver of stroke survivors: A randomised controlled trial. Int J Nurs Stud. 2018;87:84-93. https://doi. org/10.1016/j.jinurstu.2018.07.005 PMid:30059815

11. Kamal AK, Khoja A, Usmani B, Muqeet A, Zaidi F, Ahmed M, et al. Translating knowledge for action against stroke--using 5-minute videos for stroke survivors and caregivers to improve post-stroke outcomes: Study protocol for a randomized controlled trial (Movies4Stroke). Trials. 2016;17(1):52. https:// doi.org/10.1186/s13063-016-1175-x

PMid:26818913

12. Trihandini B, Fatmasari D, Hartati YK, Sudirman S. Effect of spiritual nursing care on the level of anxiety in patients with stroke. Belitung Nurs J. 2018;4(1):98-103. https://doi. org/10.33546/bnj.346

13. Tseng CN, Huang GS, Yu PJ, Lou MF. A qualitative study of family caregiver experiences of managing incontinence in stroke survivors. PLoS One. 2015;10(6):e0129540. https://doi. org/10.1371/journal.pone. 0129540

PMid:26066345

14. Deng Y, Wang J, He G, Qu F, Zheng M. Mobilization of endothelial progenitor cell in patients with acute ischemic stroke. Neurol Sci. 2018;39(3):437-43. https://doi.org/10.1007/ s10072-017-3143-y PMid:29147957

15. Caro CC, Costa JD, Da Cruz DM. Burden and quality of life of family caregivers of stroke patients. Occup Ther Health Care. 2018;32(2):154-71. https://doi.org/10.1080/07380577.2018.144 9046

\section{PMid:29578827}

16. Riegel B, Moser DK, Buck HG, Dickson VV, Dunbar SB, Lee CS, et al. Self-care for the prevention and management of cardiovascular disease and stroke: A scientific statement for healthcare professionals from the American Heart Association. J Am Heart Assoc.2017;6(9):e006997. https://doi.org/10.1161/ JAHA.117.006997

PMid:28860232

17. De Bruijn MA, Synhaeve NE, van Rijsbergen MW, de Leeuw FE, Mark RE, Jansen BP, et al. Quality of life after young ischemic stroke of mild severity is mainly influenced by psychological factors. J Stroke Cerebrovasc Dis. 2015;24(10):2183-8. https:// doi.org/10.1016/j.jstrokecerebrovasdis.2015.04.040 PMid:26215135

18. Nozoe, M., Yamamoto, M., Kobayashi, M., Kanai, M., Kubo, H., Shimada, S., \& Mase, K. (2018). Heart rate variability during early mobilization in patients with acute ischemic stroke. Eur Neurol. 2018;80(1-2):50-4. https://doi.org/10.1159/000492794 PMid:30205405

19. Camicia M, Lutz BJ, Markoff N, Catlin A. Determining the needs of family caregivers of stroke patients during inpatient rehabilitation using interview, art, and survey. Rehabil Nurs. 2019;44(6):32837. https://doi.org/10.1097/RNJ.0000000000000129 PMid:29300229

20. Panzeri A, Rossi Ferrario S, Vidotto G. Interventions for psychological health of stroke caregivers: A systematic review. Front Psychol. 2019;10:2045. https://doi.org/10.3389/ fpsyg.2019.02045

PMid:31551881

21. Knight, C. J., Jackson, O., Rahman, I., Burnett, D. O., Frugé, A. D., \& Greene, M. W. (2019). The mediterranean diet in the stroke belt: A cross-sectional study on adherence and perceived knowledge, barriers, and benefits. Nutrients. 2019;11(8):1847. https://doi.org/10.3390/nu11081847 PMid:31404958

22. Laures-Gore JS, Lambert PL, Kruger AC, Love J, Davis DE. Spirituality and post-stroke aphasia recovery. J Relig Health. 2018;57(5):1876-88. https://doi.org/10.1007/ s10943-018-0592-4

\section{PMid:29541973}

23. Ronaldson S, Hayes L, Aggar C, Green J, Carey M. Palliative care nurses' spiritual caring interventions: A conceptual understanding. Int J Palliat Nurs. 2017;23(4):194-201. https:// doi.org/10.12968/ijpn.2017.23.4.194 PMid:28486071

24. Pucciarelli G, Vellone E, Savini S, Simeone S, Ausili D, Alvaro $\mathrm{R}$, et al. Roles of changing physical function and caregiver burden on quality of life in stroke: A longitudinal dyadic analysis. Stroke. 2017;48(3):733-9. https://doi.org/10.1161/ STROKEAHA.116.014989

PMid:28196939

25. Chafjiri RT, Navabi N, Shamsalinia A, Ghaffari F. The relationship between the spiritual attitude of the family caregivers of older patients with stroke and their burden. Clin Interv Aging. 2017;12:453-8. https://doi.org/10.2147/CIA.S121285

PMid:28280318 